\title{
Biometry of Hard Palate on Digital Photographs: A Methodology for Quantitative Measurements
}

\author{
Biometría del Paladar Duro en Fotografías Digitales: Una Metodología para Mediciones Cuantitativas \\ "Rafael Saviolo Moreira; "Emerson Alexandre Sgrott; *Fernando Seiji \& *** Ricardo Luiz Smith
}

\begin{abstract}
MOREIRA, R. S.; SGROTT, E. A.; SEIJI, F. \& SMITH, R. L. Biometry of hard palate on digital photographs: A methodology for quantitative measurements. Int. J. Morphol., 24(1):19-23, 2006.

SUMMARY: The objective of this paper is to establish, validate and test the reproducibility and accuracy of a digital method to measure linear and angular distances in human hard palate of dry skulls. Digital photographs were made in 10 human adult skulls and measurements were made with the aid of AutoCAD software and with a digital caliper in the same skulls by one observer in a blind fashion to compare both methods. To validate the digital method, measurements was made in 20 skulls by 3 observers. The differences of the measurements were not statistically significant between both method and between the 3 observers. The use of digital cameras followed by image analysis with AutoCAD, a software initially developed for engineering and architecture, revealed to be an excellent tool for biometry in morphology in medical and dentistry areas combining easy handling with accessibility.
\end{abstract}

KEY WORDS: Biometry; Palate; Digital photography; Anthropometry.

\section{INTRODUCTION}

The hard palate is an essential region of the skull formed by the two palatal process of maxilla and two horizontal plates of the palatine bones which are linked by a crucial suture formed by the junction of the four described bones (Williams, 1995; Sicher \& DuBrul, 1977). The morphological appearance of palate (Lee et al., 2001; Skrzat et al., 2003b) and its dimensions (Woo, 1949; Hassanali \& Mwaniki, 1984; Skrzat et al., 2003a) has been of interest in many studies. For biometry and asymmetry evaluations, radiographic assessment or metric methods, using spreading caliper or compasses directly in the subject are applied. The morphology of palate can be assessed by straightforward visual inspection (Westmoreland \& Blanton, 1982; Rossi et al., 2003, Skrzat et al., 2003b; Alcocer et al., 2004). The methods described, are considered gold standard methods for biometry (Frasseto, 1918; Comas, 1957). However, with the increase use and popularity of the digital photographs, new methodologies have been developed to make easy some procedures and to opens up new possibilities of action (Becker et al., 1998; Becker \& Svensson, 1998). The AutoCAD ${ }^{\circledR}$, a software initially developed for engineering and architecture, recently revealed itself as an excellent tool for biometry in medicine and dentistry field (Siu et al., 1996; McArthur et al., 1998; Sánchez-Pérez et al., 2001; Aigner et al., 2004; Iqbal et al., 2004; Masiero \& Barletta, 2005).

After extensive database search we are unaware of a methodology that combines digital photographs and AutoCAD ${ }^{\circledR}$ software to measure distances in the area of the hard palate. Our goal is to establish and validate a method to acquire biometry data for this region. To this aim, we focused on landmarks that are commonly used in conventional anthropometry to obtain measures using digital photographs processed with the software AutoCAD ${ }^{\circledR}$. Furthermore, we tested the reproducibility and accuracy of the method by means of intra and inter observer analysis and compared this methodology with the traditional caliper method.

* Rafael Saviolo Moreira, D. D. S., M. Sc., Professor, Human Anatomy Department, UNIVALI, Itajaí, Brazil - and Ph. D. student, Department of Morphology, UNIFESP, São Paulo, Brazil.

* Emerson Alexandre Sgrott, D.D.S., Ph. D., Professor, Human Anatomy Department, UNIVALI, Itajaí, Brazil, Santa Catarina, Brazil.

** Fernando Seiji, Professor, Human Anatomy Department, UniFMU, São Paulo, Brazil - M. Sc. student, Department of Morphology, UNIFESP, -São Paulo, Brazil.

**** Ricardo Luis Smith. M.D., Ph.D., Full Professor and Chairman, Department of Morphology, UNIFESP - São Paulo, Brazil. 


\section{MATERIAL AND METHOD}

This work was divided in two parts. To ascertain if the method accurately reproduce the real dimensions of the palate, first, an examiner measure anthropometrical dimensions in 10 dry adult skulls to compare the digital photographs methodology with the conventional one. In a second stage, we used 20 hard palates of dry skulls to compare the digital methodology among three observers to evaluate reproducibility and accuracy of the methodology. All the skulls were of adult humans of both sexes, pertaining to the Museum of Department of Morphology, Federal University of, São Paulo. As criteria of inclusion, none of the skulls presented fractures, malformations, damage due to conservation or pathologies that could influence the development of the studied region. All palates were photographed by a modification of the protocol described by Aigner et al. The modification consisted in stabilize the skulls in a horizontal surface and take pictures with the palate plane parallel to camera lens. We used a digital camera Nikon Coolpix 4300 (4.0 Megapixels, Nikon Corp, Japan) on a photographic tripod (Manfrotto, Italy). All skulls had been placed in the same standard position. For this, we used two laterals and one posterior acrylic frame stabilizers and one central set frame used as parameter to set the palate plane parallel to the camera's one (Fig. 1). Although the focal distance could be modified (even a minimum), each pictures had a scale of $10 \mathrm{~mm}$ fixed in palate plainer region. After complete position of skull and acrylic frames, the set frame was removed and the photographs of palate were taken. The images were stored in a memory card and transfered to a PC unit. Each picture was independently resized in the software. Due to individually resize, all the pictures have the real dimensions independently of any alterations on the focal length. The measures had been carried out with the software AutoCAD ${ }^{\circledR}$ 2004 (Autodesk Inc., San Rafael, CA, USA).
First, to compare the digital anthropometry methodology with the traditional one, we used digital spreading caliper (Mitutoyo Corp., Japan) with accuracy of 0,01 $\mathrm{mm}$. The distance between common anthropometrical points (below cited) of 10 skulls had been measured using the two methodologies. Only one observer did the measures in a blind way.

In the second stage, to validate and to test reproducibility and accuracy of the digital methodology of biometry, 20 skulls were evaluated by each of three different examiners. Eleven distances was defined in palate. All the appraisers had received one table with the landmarks, measures to be calculated and instructions of how operate the software. Only one of the appraisers had previous knowledge on software and the region studied.

The distances and landmarks selected followed anthropological principals (according to Frasseto and Skrzat $e t$ al., 2003a). The digital biometry allows a great magnification of the image without losing quality. In this case is necessary to limit the boundaries of the structures and landmarks, to determine which point will be used (Fig. 2).

The anthropological points used were:

INC - incisulare, the "place of direct contact between the median palatine suture and the posterior margin of incisive foramen" (Skrzat et al., 2003a). Frasseto call this point as porion but we prefer the terminology defined by Skrzat et al. (2003a).

SR - staurion, point of intersection between the median and interpalatine suture and transverse palatine suture (Frasseto; Skrzat et al., 2003a). In some skulls, the two halves of the palatal
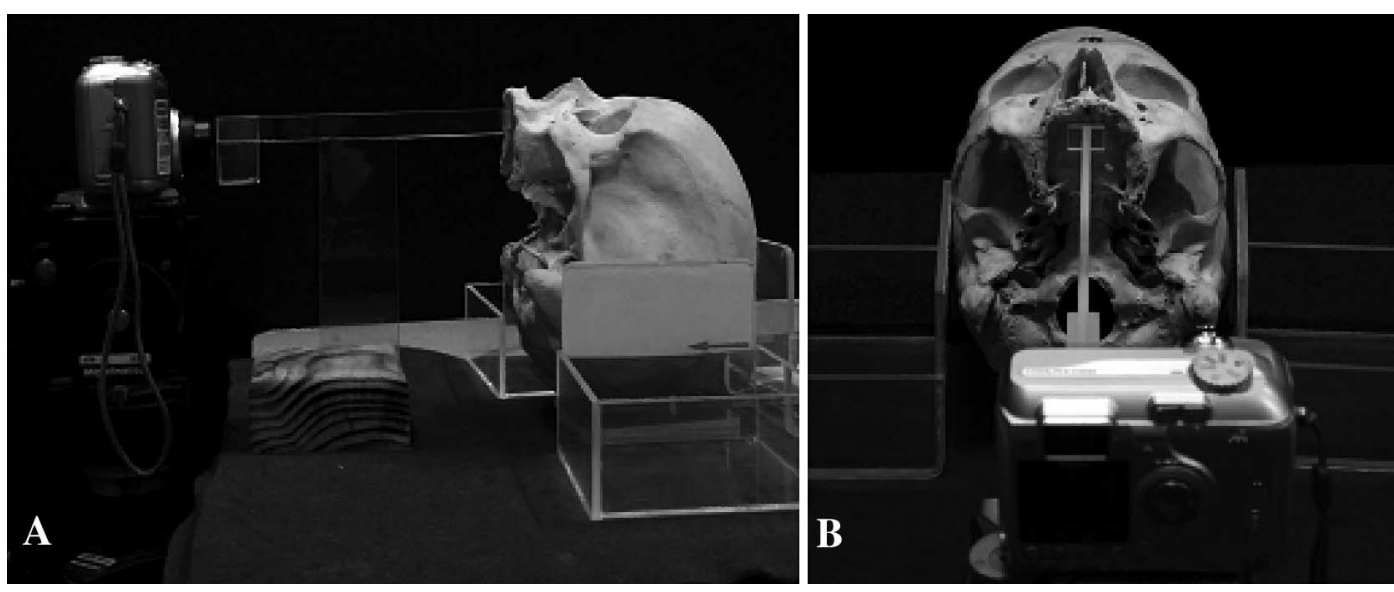

Fig. 1-A (lateral view) and B (frontal view) shows the set with the digital camera in tripod and the two laterals and one posterior acrylic frame stabilizers. The palate is parallel to camera's focal plane due to the central set frame. Before shoot the camera, the central frame was removed. 
shelves which form the transverse palatine sutures do not meet in the same point; in these cases, the point nearer to the INC was considered.

PNS - the more posterior and median point of posterior nasal spine.

GPF - the median point of the posterior margin of greater palatine foramen.

The following linear and angular measures were applied:

\section{Linear Measures.}

1. INC x SR - length of the median palatine suture, the anterior portion of hard palate.

2. SR $x$ PNS - length of the interpalatine suture, the posterior portion of the hard palate.

3. INC $x$ PNS - the sum of the two previous measures.

4. INC $x$ GPF - length of the INC to the GPF.

5. GPF $x$ PNS - length of the GPF to the PNS.

6. GPFr x GPFl - length between the right(r) and left (l) GPF, (length of the transverse palatine suture).

\section{Angular Measures}

7. Angle INC x PNS x GPF - measure the angular position of the GPF, in relation to the median sagital plan of the hard palate, having as the reference point, the posterior nasal spine.

8. Angle INC x SR x GPF - measure the angular position of the GPF, in relation to the median sagital plan of the hard palate, having as the reference point, the staurion.

\section{RESULTS}

The results obtained from measurements with the conventional and the digital biometry is presented in Table I. The analysis of variance (ANOVA) established that the difference of the means is not statistically significant for all five measures. All measures have a high relation coefficient with exception of the right side of PNS x GPF (despite the ANOVA proved the there's no statistically significant

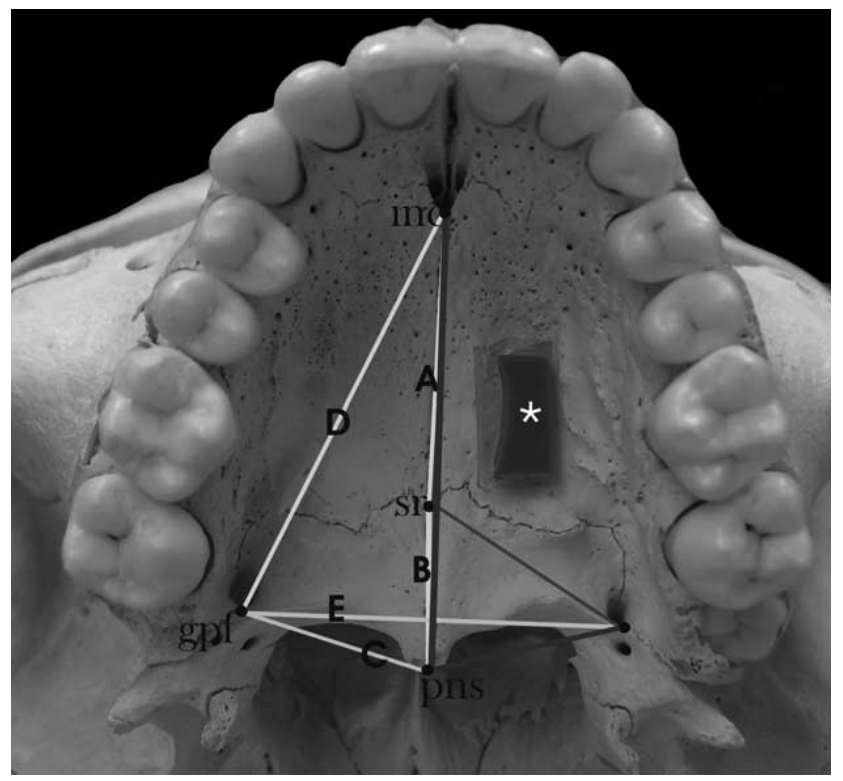

Fig. 2 - Anthropometrical landmarks, linear and angular measure on the hard palate used to compare the two techniques. The asterisk shows the scale (10 $\mathrm{mm}$ on its plane side). Light lines show linear lenghts: A - inc x sr; B - sr x pns; C - pns x gpf; D - gpf x inc; E - gpfr $\mathrm{x}$ gpfl. Dark lines show the angular measures: inc $\mathrm{x}$ sr $\mathrm{x}$ gpf e inc $\mathrm{x}$ pns x gpf. Anthropometrical landmarks: inc - incisulare; sr - staurion; pns - posterior nasal spine; gpf - greater palatine foramen.

differences between the means). The measure with the higher relation coefficient was INC x GPF. To evaluate reproducibility and accuracy of digital biometry, 3 examiners measured 12 distances in 20 different skulls. There were no statistically significant differences between the means for all examiners. The coefficient level (p) ranged from 0,604 up to 0,997 .

Table I. Mean values (in $\mathrm{mm}$ ) and statistical results for the two methods of biometry, the conventional caliper and the digital biometry in 10 skulls.

\begin{tabular}{|c|c|c|c|c|c|c|c|c|}
\hline \multirow{2}{*}{\multicolumn{2}{|c|}{ MEASURES }} & \multirow{2}{*}{ INC $x$ SR } & \multirow{2}{*}{ SR $x$ PNS } & \multirow{2}{*}{$\begin{array}{l}\text { INC } x \\
\text { PNS }\end{array}$} & \multicolumn{2}{|c|}{ INC x GPF } & \multicolumn{2}{|c|}{ PNS x GPF } \\
\hline & & & & & $\mathbf{R}$ & $\mathbf{L}$ & $\mathbf{R}$ & $\mathbf{L}$ \\
\hline \multirow[b]{2}{*}{$\operatorname{Mean}(\mathrm{x})$} & Caliper & 27,99 & 13,43 & 41,90 & 40,98 & 41,76 & 17,89 & 17,56 \\
\hline & $\begin{array}{c}\text { Digital } \\
\text { photographs }\end{array}$ & 27,22 & 13,82 & 41,19 & 41,15 & 41,48 & 16,93 & 16,82 \\
\hline \multicolumn{2}{|c|}{ Diference $(\mathrm{mm})$} & 0,77 & 0,39 & 0,71 & 0,17 & 0,28 & 0,96 & 0,74 \\
\hline \multicolumn{2}{|c|}{ ANOVA $(p)$} & 0,571 & 0,779 & 0,418 & 0,855 & 0,853 & 0,239 & 0,164 \\
\hline
\end{tabular}




\section{DISCUSSION}

To our knowledge, this study is the first attempt to use the software AutoCAD ${ }^{\circledR}$ with digital photographs to evaluate dimensions on the hard palate. Digital biometry brings new potential of clinical value (to orthodontics) and others correlation fields (anthropometry and anatomy). Although the conventional method of biometry (with caliper or compasses) is a well established and a reliable one (Frasseto), biometry in digital photographs has a great potential, many advantages and leads to new possibilities in the area of biometry (Becker \& Svensson, 1998). Some advantages of this methodology over the traditional one are: 1) this prove to be accurate, less time-consuming and with excellent reproducibility of landmarks; 2) as the software saves the point choose to linear measurements, the angular ones were calculated with the same landmarks making the procedure easier; 3 ) the study of subjects can be completely done away from the original place; 4) the subjects (which are very delicate) don't have to be too handled, avoiding damage; 5) the digital photographs (created with a high degree of resolution) and the studied protocol of each subject can be stored in digital media and retrieve whenever its necessary for reevaluation; when the file is open, we have all the original measures and traced lines in the screen making ease the process of reevaluation. The digital biometry brings together reliable objective measurements of rectilinear distances and angles as well subjective onscreen morphology evaluation (Becker et al.). Also, the required time consuming for the measurements is further less. We avoid parallax distortion of photographs with a scale in the plane part of palate and a set of acrylic positioner frame. One limitation of the methodology is the planification of image. It is useful that the dimensions of studied areas do not suffer dimensional alterations with the two-dimensional transformation (Hurwitz et al., 1999).

Comparing the two methods of biometry, digital and traditional, the lesser descriptive level (p) and correlation coefficient was PNS to GPF length in both sides, left and right. This is probably related to the difficulty to delimitate landmarks with the digital spreading caliper. During the photography software analysis, it's very easy and simple to reproduce the landmarks. With the spreading caliper, it's not easy to maintain the two points, always in the same place. Even the difference is by few parts of millimeters, discrepancy between the measures occurs.

Regarding the inter observer evaluation, ANOVA showed that all twelve measures was not statistically different ( $\mathrm{p}$ value varied from 0,60 to 0,99 ). To confirm the modus operandi and show its ease to management, we should consider that only one observer have had previous contact with the software, the other two observers received the landmarks to be use and the commands of the software.

Although few limitations, biometry of the hard palate in digital photographs with the AutoCAD ${ }^{\circledR}$ software is a methodology which shows many advantages and possibilities to anthropometry and correlated fields (Hurwitz et al.). When applied as indicated, is an excellent method to assess both linear and angular measures on images where the planification of structures doesn't alter the real 3D image dimensions. Besides the simple way to store the images (digital media), it's easy to change and export information.

\section{ACKNOWLEDGEMENTS}

The authors thanks to Ana Paula Piccoli and Carolina Lima Vaz for the time available to participate on this project and also acknowledge Miss Elisandra Kamer Fiamoncini for her great support on statistical analysis.

MOREIRA, R. S.; SGROTT, E. A.; SEIJI, F. \& SMITH, R. L. Biometría del paladar duro en fotografías digitales: Una metodología para mediciones cuantitativas. Int. J. Morphol., 24(1):19-23, 2006.

RESUMEN: Los objetivos de este trabajo fueron establecer, validar y probar la reproductividad y exactitud de un método digital para medidas lineares y distancia angular en el paladar duro de cráneos humanos secos. Fotografías digitales fueron realizadas en 10 cráneos de hombres adultos. Las medidas fueron tomadas con la ayuda del software AutoCAD ${ }^{\circledR}$ y con un caliper digital en las muestras de cráneos, por un observador, para comparar ambos métodos. Para validar el método digital, fueron realizadas mediciones en 20 cráneos, por 3 observadores. Las diferencias de las mediciones no fueron estadísticamente significativas entre ambos métodos y entre los 3 observadores. El uso de cámaras digitales, seguido por análisis de imágenes con AutoCAD ${ }^{\circledR}$, un software inicialmente desarrollado para ingeniería y arquitectura, reveló ser una excelente herramienta para biometría en morfología, en las áreas de medicina y odontología, combinando un fácil manejo y accesibilidad.

PALABRAS CLAVE: Biometría; Paladar; Fotografía digital; Antropometría. 


\section{REFERENCES}

Aigner, F.; Longato, S.; Fritsch, H. \& Kralinger, F. Anatomical considerations regarding the "bare spot" of the glenoid cavity. Surg. Radiol. Anat., 26:308-11, 2004.

Alcocer, A.T.; Martinez, J. B. \& Milián, F. Morphometric correlation of the palate in infant skulls in different stages of occlusal development. Int. J. Jaw Functional Orthop., 1(2):128-41, 2004.

Becker, M.; Svensson, H. \& Jacobsson, S. Clinical examination compared with morphometry of digital photographs for evaluation of repaired cleft lips. Scand. J. Plast. Reconstr. Surg. Hand Surg., 32(3):301-6, 1998.

Becker, M. \& Svensson, H. Morphometry in digital photographs: a promising technique for assessing patients with cleft lip and palate. Scand. J. Plast. Reconstr. Surg. Hand Surg., 32(3):295-9, 1998.

Comas, J. Manual de Antropología Física. México, Fondo de Cultura Económica, 1957.

Frasseto, F. Lezioni di Antropologia. 2. ed. Milano, Ulrico Hoepli. Vol Secondo - parte 1, 1918.

Hassanali, J. \& Mwaniki, D. Palatal Analysis and osteology of the hard palate of the Kenyan African skulls. Anat. Rec., 209:273-80, 1984.

Hurwitz, D. J.; Ashby, E.R.; Llull, R.; Pasqual, J.; Tabor, C.; Garrison, L.; Gillen, J. \& Weyant, R. Computer-assisted anthropometry for outcome assessment of cleft lip and palate. Plast. Reconstr. Surg., 103:1608-23, 1999.

Iqbal, M. K.; Firic, S.; Tulcan, J.; Karabucak, B. \& Kim, S. Comparison of apical transportation between ProFile and ProTaper NiTi rotary instruments. Int. Endod. J., 37(6):35964, 2004.

Lee, S. P.; Paik, K.S. \& Kim, M.K. Variations of the prominences of the bony palate and their relationship to complete dentures in Korean skulls. Clin. Anat., 14:324-9, 2001.

Masiero, A.V. \& Barletta, F.B. Effectiveness of different techniques for removing gutta-percha during retreatment. Int. Endod. J., 38(1):2-7, 2005.

McArthur, P. A.; Cutts, A.; Milner, R. H. \& Johnson, G.R. A study of the dimensions and taper angles of the medullary canals of the proximal and middle phalanges. J. Hand Surg., 23(1):24-7, 1998.
Rossi, M.; Ribeiro, E. \& Smith, R. Craniofacial asymmetry in development: an anatomical study. Angle Orthod., 73(4):381-5, 2003.

Sánchez Pérez, A.; Honrubia López, F.M.; Larrosa Poves, J.M.; Polo Llorens, V. \& Melcon Sanchez-Frieras, B. The Autocad system for planimetric study of the optic disc in glaucoma: technique and reproducibility study Arch. Soc. Esp. Oftalmol., 76(9):551-8, 2001.

Skrzat, J.; Holiat, D. \& Walocha, J. A morphometrical study of the human palatine sutures. Folia Morphol., 62(2):1-9, 2003a.

Skrzat, J.; Holiat, D. \& Walocha, J. The morphological appearance of the palatine torus in the Cracovian skulls (XVXVIII century). Folia Morphol., 62(3):183-6, 2003 b.

Sicher, H. \& DuBrul, E. L. Anatomia Bucal. 7.ed. Rio de Janeiro, Guanabara Koogan, p38, 1977.

Siu, D.; Rudan, J.; Wevers, H.W. \& Griffiths, P. Femoral articular shape and geometry. A three-dimensional computerized analysis of the knee. J. Arthroplasty., 11(2):166-73,1996.

Westmoreland, E. E. \& Blanton, P. L. An analysis of the variations in position of the greater palatine foramen in the adult human skull. Anat. Rec., 204:383-8, 1982.

Williams, P. L. (ed). Gray's Anatomy. 38.ed. New York, Churchill Livingstone, 1995.

Woo, J. Direction and type of the transverse palatine suture and its relation to the form of the hard palate. Am. J. Phys. Anthropol., 7:385-99, 1949.

Correspondence to:

Prof. Rafael Saviolo Moreira

Universidade do Vale do Itajai - UNIVALI

Centro de Ciências da Saúde

Laboratório de Anatomia Topográfica e Descritiva

Bloco 24 B - Sala 101

Rua Uruguai, 458 Centro

Itajá - Santa Catarina - CP 360

BRASIL

Received: 12-09-2005

Accepted: 28-11-2005 